\title{
Nalaz patogenih bakterija u sirovom mlijeku i mliječnim proizvodima s posebnim osvrtom na vistu Yersinia
} enterocolitica

\author{
V. Jaki Tkalec*, S. Furmeg, M. Kiš, J. Sokolović, M. Benić, L. Cvetnić, \\ Ž. Pavlinec, S. Špičić i Ž. Cvetnić
}

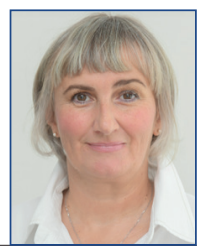

\section{Sažetak}

U sjeverozapadnoj Hrvatskoj meki svježi sir se tradicionalno proizvodi po nepisanoj recepturi od sirovog kravljeg mlijeka. Mlijeko predstavlja idealan supstrat za rast i razmnožavanje brojnih mikroorganizama, mnogih uzročnika zoonoza pa tako i vrste Y. enterocolitica. Tijekom naših istraživanja pretraženo je 159 uzoraka, od toga 109 uzoraka sirovog kravljeg mlijeka i 50 uzoraka svježeg kravljeg sira i vrhnja. Y. enterocolitica izdvojena je iz dva $(1,8 \%)$ uzorka sirovog mlijeka. Od 50 uzoraka mliječnih proizvoda (sir i vrhnje) u 16 (32\%) njih je dokazana E. coli, u 12 (24\%) uzoraka $S$. aureus te u jednom (2\%) uzorku $L$. innocua. Osim njihu 15 (13,8\%) uzoraka sirovog mlijeka i 24 (48 \%) uzorka svježeg sira i vrhnja izdvojene su enterobakterije, a biokemijski su identificirane vrste: S. marcescens, $S$. liquefaciens, M. morganii, C. freundii i C. braakii. Bakterije iz roda Salmonella i L. monocytogenes u istraživanim uzorcima nisu dokazane. Nakon provedene biokemijske identifikacije, dva soja identificirana kao vrsta Y. enterocolitica pretraženi su na molekularnoj razini. Molekularnom pretragom potvrdni rezultat dobiven je samo kod jednog uzorka, što je usporedivo s rezultatima drugim istraživanja. Zbog zahtjevne identifikacije bakterijske vrste Y. enterocolitica, kombiniranom primjenom uzgojnih i molekularnih metoda dobivaju se pouzdaniji i brži rezultati identifikacije. Sirovo mlijeko i vrhnje od sirovog mlijeka izvor su patogenih mikroorganizama (E. coli i S. aureus) i drugih enterobakterija, a našim istraživanjem dokazali smo i patogenu bakterijsku vrstu $Y$. enterocolitica koja predstavlja potencijalni rizik za zdravlje potrošača i u Republici Hrvatskoj. $Y$. enterocolitica je otporna na procese $u$ proizvodnji hrane (dezinfekcija, niski $\mathrm{pH}$, salinitet, preživljavanje $u$ hladnijim uvjetima) te $u$ budućnosti zahtijeva veću pažnju i nadzor u proizvodnji hrane.

Ključne riječi: Y. enterocolitica, bakterije, sirovo mlijeko, sir i vrhnje

Dr. sc. Vesna JAKI TKALEC ${ }^{*}$, dr. med. vet., znanstvena suradnica, (dopisni autor, e-mail: jaki.vzk@veinst.hr), Sanja FURMEG, dipl. sanit. ing., dr. sc. Maja KIŠ, mag. ing. bioproc., mag. ing. agr., Jadranka SOKOLOVIĆ, dr. med. vet., Hrvatski veterinarski institut, Veterinarski zavod Križevci, Križevci, Hrvatska; dr. sc. Miroslav BENIĆ, dr. med. vet., naslovni docent, znanstveni savjetnik, dr. sc. Luka CVETNIĆ, dr. med. vet., Željko PAVLINEC, mag. biol. mol., dr. sc. Silvio ŠPIČIĆ, dr. med. vet., znanstveni savjetnik, Hrvatski veterinarski institut, Zagreb, Hrvatska; dr. sc. Željko CVETNIĆ, dr. med. vet., akademik, Hrvatski veterinarski institut, Veterinarski zavod Križevci, Križevci, Hrvatska 


\section{Uvod}

U današnje vrijeme, kada u proizvodnji hrane prevladavaju suvremene tehnologije, tradicionalna proizvodnja autohtonih mliječnih proizvoda, a osobito sireva, dobiva sve veće značenje. Odlika tradicijskih sireva je: originalnost tehnologije proizvodnje bez dodataka komercijalnih kultura i aditiva te podrijetlo sirovog mlijeka. Zbog toga je u proizvodnji sireva važno osigurati mlijeko besprijekorne mikrobiološke čistoće (Zebec, 2016.). Proizvodnja sireva od sirovog mlijeka predstavlja i značajan javnozdravstveni problem, jer se radi o namirnici koja može biti izvor različitih uzročnika bolesti. Mlijeko je sirovina vrlo pogodna za rast i razvoj brojnih mikroorganizama poput enterobakterija, koje su pokazatelj propusta u higijeni tijekom proizvodnje, zatim kvasaca plijesni, ali i drugih patogena poput Staphylococcus (S.) aureus, Listeria (L.) monocytogenes i mnogih drugih (Kozačinski i sur., 2003., Markov i sur., 2009., Hammer i sur., 2017., Van Der Brom i sur., 2020.). Mlijeko je idealan medij i za rast psihrotrofne Yersinia (Y.) enterocolitica koja se u mlijeku može unutar nekoliko sati na temperaturi hlađenja umnožiti do količine koja se smatra zaraznom. (Bursová i sur., 2017.). Psihrotrofne bakterije, koje karakterizira rast na temperaturama hlađenja smatraju se najčešćim uzročnicima kvarenja mlijeka. Psihrotrofna mikrobna populacija, potječe iz: okoline, raslinja, higijenski neispravne vode, nedovoljno čistih muznih uređaja i opreme za transport i pohranu mlijeka (Hahn, 1996.). Sirovo mlijeko i sirevi ponekad mogu u visokom postotku sadržavati $Y$. entererocolitica (Schiemann, 1978., Hanifian i Khani, 2012.). Infekcije prouzročene vrstom $Y$. enterocolitica rasprostranjene su širom svijeta. Vrsta Y. enterocolitica proširena je u tlu, vodi i okolišu u kojem dugo zadrži infektivnost, osobito na hladnim i vlažnim mjestima. Sposobna je umnožavati se na temperaturama hladnjaka, koje inače inhibiraju rast većine patogena koji mogu prouzročiti trovanje hranom (Naglić i sur., 2005.). Unutar vrste Y. enterocolitica ima više biotipova i serovarova (1A, 1B, 2, 3, 4 i 5). Biotipovi 1B i 2,3,4 i 5 se smatraju patogenim, a biotip 1A apatogenim. Vrsta je podijeljena u 76 seroloških skupina, a pojedini serovarovi nalaze se $u$ više genomskih vrsta (Zadernowska i sur., 2014.). Y. enterocolitica može prouzročiti različite oblike bolesti, od blagog enteritisa do ozbiljnih općih infekcija. Na razini Europske unije, od 26 članica u 2017. godini potvrđeno je 6823 slučaja jersinioze, što ovu bolest svrstava među tri najčešće prijavljivane zoonoze $\mathrm{u} \mathrm{EU}$ (EFSA, 2018.).

$\mathrm{Za}$ razliku od nekih drugih vrsta, pojavnost patogene vrste $Y$. enterocolitica u mliječnim proizvodima nije dovoljno istražena. S obzirom da su svježi mliječni proizvodi, koji čine pogodan supstrat za njezin razvoj, svakodnevno tradicionalno jelo, a proizvođačima je omogućeno izravno stavljanje na tržište takvih proizvoda, postoji stalna opasnost za zdravlje ljudi. Stoga je cilj našeg istraživanja bio ustvrditi prisutnost bakterijske vrste $Y$. enterocolitica $u$ sirovom mlijeku i tradicionalnim mliječnim proizvodima.

\section{Materijali i metode}

Uzorci: Istraživanje je provedeno na ukupno 159 uzoraka sirovog mlijeka i proizvoda od mlijeka. Od toga je 109 uzoraka bilo sirovo mlijeko (skupni uzorci stajskog mlijeka) i 50 uzoraka vrhnja i svježeg mekog sira od sirovog mlijeka. Uzorkovanje je obavljeno kod individualnih proizvođača iz sjeverne Hrvatske koji svoje proizvode prodaju „na vlastitom pragu“ ili na tržnicama grada Zagreba i Križevaca. Uzorci sira su 
uzeti sterilnim žlicama za uzorkovanje i stavljani su u sterilne posude, a mlijeko u sterilne bočice. Neposredno nakon uzorkovanja, uzorci su dostavljeni u laboratorij i podvrgnuti mikrobiološkom pretraživanju.

Mikrobiološka analiza: Mikrobiološka pretraga, priprema uzoraka mlijeka, sira i vrhnja obavljena je standardnim normiranim postupcima (u skladu s ISO normama) za pojedini mikroorganizam.

Uzorci sirovog mlijeka (skupni uzorci stajskog mlijeka) pretraživani su na ukupan broj mikroorganizama. Metoda određivanja ukupnog broja mikroorganizama u mlijeku izvodi se nacjepljivanjem deseterostrukih razrjeđenja na hranjivu podlogu Plate count agar (PCA, Merck, Darmstad, Njemačka). Uzorak mlijeka (1 $\mathrm{mL})$ odmjeri se u $9 \mathrm{~mL}$ puferirane peptonske vode, a postupak se ponavlja do željenog razrjeđenja. Nacjepljuje se na PCA i inkubira $u$ termostatu na temperaturi od $30{ }^{\circ} \mathrm{C}$ tijekom 72 sata. Kolonije se broje pomoću brojača kolonija, a broj kolonija izračunava se uvrštavanjem dobivenih vrijednosti u formulu $\mathrm{N}=\Sigma \mathrm{C} /\left(\mathrm{n}_{1}+0,1 \mathrm{n}_{2}\right) \mathrm{d}$.

Za dokaz prisutnosti bakterija iz roda Salmonella spp. u siru i vrhnju, korišten je tekući neselektivni bujon za prednamnažanje, tekući selektivni mediji za namnažanje i krute selektivne podloge, Xylose lysine deoxycholate agar (XLD, Biokar, Allonne, Francuska) i Rambach agar (Merck, Darmstadt, Njemačka), a cijeli postupak izveden je prema ISO normi HRN EN ISO 6579 -1. Za dokaz prisutnosti Listeria spp. korišten je Fraser bujon (Biokar, Allonne, Francuska) za primarno i sekundarno namnažanje te krute selektivne podloge Agar Listeria prema Ottaviani i Agosti (ALOA, Biolife, Francuska) i Palcam agar (Biokar, Allonne, Francuska) (prema HRN EN ISO 11290-1.). Za dokazivanje prisustva i određivanje broja bakterijske vrste Escherichia coli korišten je tryptone bile glucuronic agar (TBX, Merck,
Darmstadt, Njemačka) (HRN ISO 16140), a za Enterobacteriaceae korišten je violet red bile agar (VRBG, Merck, Darmstadt, Njemačka) (u skladu s HRN EN ISO 21528-2). Za S. aureus i druge koagulaza pozitivne stafilokoke korišten je Baird-Parker agar (Merck, Darmstadt, Njemačka) prema normi HRN EN ISO 6888-1. Zdravstvena ispravnost proizvoda procjenjivala se prema Vodiču za mikrobiološke kriterije za hranu (2011.).

Postupak pretraživanja uzoraka radi određivanja prisutnosti bakterijske vrste $Y$. enterocolitice proveden je sukladno zahtjevima standarda HRN EN ISO 10273 pri čemu je za pripremu uzoraka i namnažanje korišten Peptone Sorbitol Broth (PSB, Sigma-Aldrich, St. Louis, SAD), inkubiran tijekom 2 dana pri $22{ }^{\circ} \mathrm{C}$ nakon čega je slijedilo nacjepljivanje na površinu cefsulodin-irgasannovobiocin agara (CIN, Oxoid, Hampshire, UK). Isti uzorak u PSB bujonu tretiran je s $\mathrm{KOH}$ nakon čega je slijedilo nacijepljivanje na površinu CIN agara. Usporedno, Irgasan Ticarcillin Chlorate bujonu (ITC, Sigma- Aldrich, St. Louis, SAD) inkubiran je tijekom 2 dana pri $25{ }^{\circ} \mathrm{C}$ nakon čega je slijedilo nacjepljivanje na površinu CIN i Salmonella/Shigella Sodium Desoxycholate Calcium Chloride agara (SSDC, Oxoid, Hampshire, UK). Nakon inkubacije na $30{ }^{\circ} \mathrm{C}$ tijekom 48 sati, karakteristične kolonije za vrstu Y. enterocolitica precijepljene su na hranjivi agar (Merck KGaA, Darmstadt, Njemačka). Određena su morfološka i mikroskopska svojstva za Y. enterocoliticu, test oksidaze, katalaze, triptofana, uree i kliglera, a zatim je provedena i biokemijska identifikacija automatskim sustavom VITEK2 (bioMerieux, Marcyi'Etoile, Francuska). Za biokemijsku identifikaciju se koristi prethodno pripremljenu bakterijsku suspenziju određene gustoće i kolorimetrijske kartice sa 47 mikrojažica ispunjenih standardiziranim dehidriranim reakcijskim medijima, 
a rezultati su očitavani prema uputama proizvođača.

Biokemijski identificirani sojevi kao grupa Y. enterocolitica pretraživani su na molekularnoj razini prema referenci Wannet i sur. (2001.). Za dokaz pripadnosti vrsti $Y$. enterocolitica korištena je reakcijska mješavina za višestruku lančanu reakciju polimerazom (multiplex PCR) s dva para početnica: A1 i A2 te Y1 i Y2. Početnice A1 i A2 služe za specifično umnažanje $Y$. enterocolitica ail gena, a početnice Y1 i Y2 za umnažanje $16 \mathrm{~S}$ rRNK gena (Tabela 1.). Referentni soj Y. enterocolitica ATCC 23715 korišten je kao pozitivna kontrola.

Reakcijska mješavina za PCR sastoji se od: $10 \mu \mathrm{L}$ HotStarTaq Master Mix-a (2x) (Qiagen), početnica A1, A2, Y1 i Y2 (0,25 $\mu \mathrm{M}$ svake), $2 \mu \mathrm{L}$ DNK uzorka te vode do ukupnog volumena $20 \mu \mathrm{L}$. Umnožavanje je provedeno u termokružniku (ProFlex PCR System, Applied Biosystems) aktivacijom polimeraze 15 minuta na $95{ }^{\circ} \mathrm{C}$, nakon čega su slijedila 36 ciklusa denaturacije 45 sekundi na $94{ }^{\circ} \mathrm{C}$, vezivanja početnica 45 sekundi na $62{ }^{\circ} \mathrm{C}$ i produživanja lanaca 45 sekundi na $72{ }^{\circ} \mathrm{C}$. Konačno produživanje je provedeno na $72{ }^{\circ} \mathrm{C}$ tijekom 7 minuta. Razdvajanje i detektiranje proizvoda umnožavanja je napravljeno na QIAxcel uređaju (Qiagen) korištenjem kita QX DNK Screening Kit.

\section{Rezultati}

Od 109 obrađenih uzoraka skupnog stajskog mlijeka 20 (18,3 \%) imalo je više od $100000 \mathrm{cfu} / \mathrm{mL}$ broja mikroorganizama

Tabela 1. Početnice korištene u pretrazi

\begin{tabular}{|c|c|c|c|}
\hline Target gene & $\begin{array}{c}\text { Primer } \\
\text { name }\end{array}$ & Sequence & $\begin{array}{c}\text { Expected } \\
\text { amplicon } \\
\text { size }\end{array}$ \\
\hline Y. enterocolitica ail gene & A1 & $5^{\circ}$ - TTA ATG TGT ACGCTG GGA GTG-3' & \multirow{2}{*}{$425 \mathrm{bp}$} \\
\hline Y. enterocolitica ail gene & A2 & 5'-GGA GTA TTC ATA TGA AGC GTC-3' & \\
\hline Y. enterocolitica $16 \mathrm{~S}$ rRNA & Y1 & $5^{\circ}$-AAT ACC GCA TAA CGT CTT CG-3' & \multirow{2}{*}{$330 \mathrm{bp}$} \\
\hline Y. enterocolitica $16 \mathrm{~S}$ rRNA & Y2 & 5'-CTT CTT CTG CGA GTA ACG TC-3’ & \\
\hline
\end{tabular}

Tabela 2. Rezultati mikrobiološkog istraživanja uzoraka sirovog mlijeka, svježeg sira i vrhnja (broj nesukladnih uzoraka)

\begin{tabular}{|l|c|c|c|}
\hline Vrsta uzorka & $\begin{array}{c}\text { Sirovo mlijeko } \\
(\%)\end{array}$ & $\begin{array}{c}\text { Svježi sir i } \\
\text { vrhnje (\%) }\end{array}$ & Ukupno (\%) \\
\hline Broj pretraženih uzoraka & 109 & 50 & 159 \\
\hline Ukupan broj mikroorganizama & $20(18,3)$ & - & - \\
\hline Y. enterocolitica & $2(1,8)$ & - & $2(1,3)$ \\
\hline E. coli & - & $16(32)$ & $16(10,1)$ \\
\hline S. aureus & - & $12(24)$ & $12(7,5)$ \\
\hline L. innucua & - & $1(2)$ & $1(0,6)$ \\
\hline Enterobakterije & $15(13,8)$ & $24(48)$ & $39(24,5)$ \\
\hline Seratia, Morganella, Citrobacter) & $37(33,9)$ & $39(78)^{*}$ & $77(47,8)^{*}$ \\
\hline Broj pozitivnih uzoraka & &
\end{tabular}

* iz jednog uzorka izdvojeno više vrsta bakterija 
pa stoga nisu bili sukladni Pravilniku o pregledu sirovog mlijeka namijenjenog javnoj potrošnji (NN 84/2016.).

Pretraživanjem 159 uzoraka sirovog kravljeg mlijeka, svježeg sira i vrhnja $Y$. enterocolitica izdvojena je iz dva (1,8\%) uzorka sirovog mlijeka od 109 pretražena, dok u 50 obrađenih uzoraka svježeg sira i vrhnja nije dokazana. Od 50 uzoraka mliječnih proizvoda (sir i vrhnje) u 16 (32\%) dokazana je E. coli, u 12 (24\%) uzoraka $S$. aureus te $\mathrm{u}$ jednom $(2 \%)$ uzorku L. innocua. Osim njih u 15 (13,8 \%) uzoraka sirovog mlijeka i 24 (48 \%) uzoraka svježeg sira i vrhnja izdvojene su enterobakterije, a biokemijski su identificirane vrste: Serratia (s.) marcescens, S. liquefaciens, Morganella morganii, Citrobacter (C.) freundii i C. braakii. (Tabela 2.). Bakterije iz roda Salmonella i Listeria (L.) monocytogenes nisu dokazane.

Nakon provedene biokemijske identifikacije, dva soja identificirana kao grupa $Y$. enterocolitica pretraživani su na molekularnoj razini, a rezultat je interpretiran $\mathrm{u}$ odnosu na prisutnost PCR proizvoda određene veličine. Iako je grupa $Y$. enterocolitica biokemijski dokazana u dva uzorka, samo kod jednog uzorka molekularnom pretragom dobiven je potvrdni rezultat. Vidljiv je

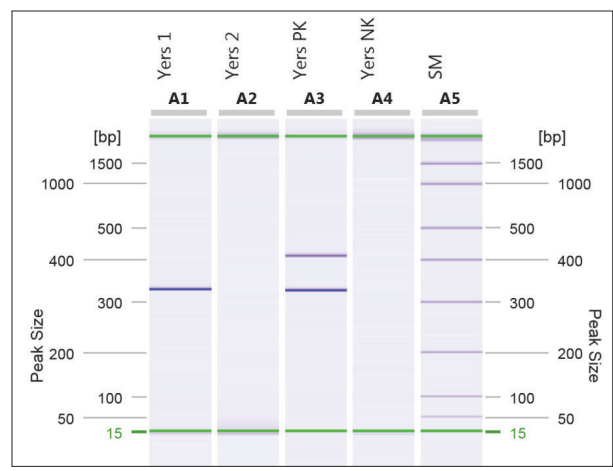

Slika 1. Prikaz agaroznog gela nakon elektroforeze kod PCR pretrage za biokemijski pozitivne uzorke $Y$. enterocolitice na kojem je vidljiv dokaz pripadnosti za vrstu $Y$. enterocolitica u uzorku Yers1 veličine 330 bp. dokaz pripadnosti za vrstu Y. enterocolitica $\mathrm{u}$ uzorku Yers1, dok u drugom uzorku Yers2 nije dokazan pripadajući gen za vrstu. U oba uzorka PCR-om nije dokazan virulentni ail marker (slika 1.).

\section{Rasprava}

U sjeverozapadnoj Hrvatskoj meki svježi sir se tradicionalno proizvodi po nepisanoj recepturi od sirovog kravljeg mlijeka. Mlijeko se nakon mužnje mora ohladiti, kiseli se samo od sebe, mora se obrati površinski skupljeno vrhnje, a preostalo mlijeko se blago zagrijava do 30-35 ${ }^{\circ} \mathrm{C}$ na rubu štednjaka kako bi došlo do koagulacije. Nastali gruš se reže na jednake dijelove da bi se odvojila sirutka i zatim izlijeva u sirne gaze (krpe) u kojima se ocjeđuje. Zbog lakorazgradivosti ugljikohidrata, masti i proteina ovako dobivena masa predstavlja idealan supstrat za rast i razmnožavanje brojnih mikroorganizama, a posebice uzročnika zoonoza među kojima je i bakterijska vrsta Y. enterocolitica (Sabljak i sur., 2013.). Enterobakterije pripadaju velikoj porodici Gram negativnih bakterija raširenih u prirodi i žive kao komenzali u probavnom sustavu ljudi i životinja i najčešći su uzrok zdravstvene neispravnosti namirnica, a šire se kontaminiranom hranom i vodom (Kalenić i sur., 2013.). E. coli je najpoznatija bakterija i smatra se dominantnom vrstom $u$ probavnom sustavu ljudi i životinja. Prisutnost ove bakterije $\mathrm{u}$ vodi i hrani pouzdan je indikator fekalnog onečišćenja (Bolton i sur., 2000.). U našem istraživanju dokazan je povećani broj mikroorganizama u sirovom mlijeku u 18,3 \% uzoraka, a enterobakterije su dokazane u 13,8\% uzoraka sirovog mlijeka i u $48 \%$ uzoraka svježeg sira, a E. coli u $32 \%$ uzoraka svježeg sira. U istraživanjima drugih autora navodi se nalaz enterobakterija $u$ rasponu od $25 \%$ do $71,4 \%$ uzoraka tvrdih i mekih sireva. Barun i sur. (2016.) izdvojili su E. coli iz 5,5\% uzoraka mekih i tvrdih sireva. 
Ljevaković-Musladin, (2007.) u Dubrovačko-neretvanskoj županiji dokazuje E. coli u 2,3\% svježih sireva. S. aureus se smatra jednim od najopasnijih patogena za ljude, ima sposobnost stvaranja enterotoksina i brzog stvaranja simptoma otrovanja iz hrane. Vrlo je često uzročnik kliničkog i supkliničkog mastitisa u preživača (Kleczkowski i sur., 2017., Benić i sur., 2018., Burović, 2020.). U našem istraživanju $S$. aureus je izdvojen iz 12 (24\%) uzoraka svježeg sira. Sabljak i sur. (2013.) navode povećan broj S. aureus u sirevima, a $25 \%$ uzoraka svježeg sira bila su mikrobiološki neispravna. Samaržija i sur. (2007.) nalaze čak 54 \% sireva pozitivnih na $S$. aureus, a autori ovako visok postotak pozitivnih uzoraka na $S$. aureus povezuju s uporabom mlijeka krava koje su imale mastitis. Cvetnić i sur. (2016.) navode da je S. aureus zastupljen u infekciji mliječne žlijezde mliječnih krava u Republici Hrvatskoj u čak $15,5 \%$ slučajeva. U mlijeku i mliječnim proizvodima nije rijetka zastupljenost i drugih patogenih mikroorganizama. Tijekom naših istraživanja nismo izdvojili vrste salmonele i L. monocytogenes, ali $\mathrm{u}$ jednom uzorku sira izdvojili smo $L$. innocua. Markov i sur. (2009.) u uzorcima svježeg sira i vrhnja domaće proizvodnje dokazuju u 66,6 \% uzoraka enterobakterije, u $41,6 \%$ S. aureus, a u $10 \%$ uzoraka L. monocytogenes. Konosonoka i sur. (2012.) navode izdvajanje vrste $\mathrm{Li}$ steria spp. iz hrane mliječnih krava i sirovog mlijeka. L. innocua izdvojena je iz $9,2 \%$, a L. monocytogenes u $20 \%$ istraživanih uzoraka. Silva i sur. (2003.) nalaze listerije duž proizvodne linije $\mathrm{u}$ jednoj mliječnoj industriji. Od 13 pozitivnih uzoraka u devet su identificirali L. innacua, u dva L. grayi i u dva L. monocytogenes.

Jersinioza je vrlo značajna zoonoza i četvrta po učestalosti kao uzrok enteritisa u Europi (Esnault i sur., 2014.). Svinje i svinjsko meso su najvažniji izvor $Y$. enterocolitica i mogu prouzro- čiti želučano-crijevne infekcije u ljudi (Laukkanen-Nimios i sur., 2014.). Prisutnost $Y$. entrocolitica ustvrđena je i $u$ drugim vrsta hrane (goveđe meso, kravlje i kozje mlijeko). Ponekad učestalost pozitivnih uzoraka na $Y$. enterocolitica $\mathrm{u}$ sirovom mlijeku može iznositi i više od $20 \%$, dok se učestalost znatno smanjuje u zrelom siru (Ahmed i sur., 2019.). U Republici Hrvatskoj je za 2017. godinu prijavljeno 17 slučajeva jersinioze, a broj slučajeva se od 2009. do 2016. kretao od sedam do 27 godišnje (HAH, 2017.). Infekcija u ljudi se najčešće očituje proljevom, visokom temperaturom, bolom $u$ trbuhu i povraćanjem, a u osoba s oslabljenim imunitetom može doći do sepse, uzrokujući vrlo teške oblike bolesti s visokom smrtnošću (Cvetnić, 2013., Le Gueren i sur., 2016.). U male djece razviju se simptomi akutnog gastroenteritisa, dok se $\mathrm{u}$ djece školske dobi i mladih obično očituje kao mezenterijalni limfadenitis praćen jakim bolovima $u$ desnom donjem kvadrantu abdomena oponašajući apendicitis (Trischler-Čeke i sur., 2008.).

Od 109 uzoraka sirovog mlijeka $\mathrm{u}$ ovom istraživanju biokemijski je $Y$. enterocolitica dokazana u dva uzorka $(1,8 \%)$. Međutim, konačnom potvrdom molekularnom metodom prisutnost bakterijske vrste Y.enterocolitica dokazana je u jednom uzorku, što je usporedivo s inozemnim istraživanjima gdje su rezultati varirali od potpuno negativnih do $25 \%$ pozitivnih uzoraka (BernardinoVaro i sur., 2013., Darwish i sur., 2015.). Vidljiva je razlika između rezultata dobivenih klasičnom metodom uzgoja na selektivnim medijima s biokemijskom identifikacijom i rezultata potvrđenih molekularnim metodama, što može biti posljedica više čimbenika. U 15 (12 \%) uzoraka sirovog mlijeka biokemijski su identificirane druge bakterijske vrste: $S$. marcescens, S. liquefaciens, M. morganii, C. freundii i C. braakii. Prisustvo velikog broja okolišne mikroflore može ometati ispravan odabir tipičnih kolonija $Y$. 
enterocolitica koje na CIN agaru rastu kao glatke kolonije s crvenijim središtem i prozirnijim rubom, a na SSDC agaru kolonije su male i sive. Enteropatogene bakterijske vrste kao što su Citrobacter freundii, Enterobacter agglomerans i Klebsiella spp. imaju sposobnost rasta na CIN agaru tvoreći slične kolonije (Fukushima, 1987.). Druga istraživanja ukazuju na ograničenost CIN agara koji inhibira rast $Y$. enterocolitica biotip 3B O:3 zbog prisustva antibiotika (Fukushima i Gomyoda, 1986.).

Psihrotrofne bakterije nisu prirodna mikrobna populacija vimena i zbog toga je njihova prisutnost $u$ sirovom mlijeku pokazatelj sekundarne kontaminacije mlijeka nakon mužnje. Njihova prisutnost može prouzročiti kvarenje mlijeka i mliječnih proizvoda. Posljedice enzimatske aktivnosti psihrotrofnih bakterija u sirovom mlijeku su neželjene promjene mliječne masti, bjelančevina i lecitina koje negativno utječu na organoleptičku i preradbenu kvalitetu (Samaržija i sur., 2012.). Czubkowska i Grazyna Rola, (2019.) su iz $65 \%$ uzoraka sirovog mlijeka izdvojili $Y$. enterocolitica, molekularno je potvrđeno da svi sojevi pripadaju tipu 1A. Dokazali su gen koji kodira za enterotoksin ystB u pripadajućem soju, dok virulentni markeri ystA i ail nisu dokazani. Usporedbom PCR i klasične metode uzgoja od ukupno 35 pozitivnih uzoraka potvrđenih klasičnom metodom uzgoja, $30(85,7 \%)$ potvrđeno je molekularnom metodom. Soj Y. enterocolitica dokazan u ovom radu iz sirovog mlijeka i potvrđen molekularno, ne sadrži kromosomski virulentni gen ail za koji je dokazano da je jedan od najpouzdanijih markera za dokaz virulentnog biotipa (Darwish i sur., 2015.). Razvojem molekularnih metoda detekcije bakterijske vrste omogućeno je razlikovati patogene od apatogenih biotipova. Patogeni biotipovi posjeduju virulentne markere (Yst-toksin, antigene Myf, Inv, Ail, plazmid pYV).
Biotip 1A ne posjeduje plazmid pYV i druge klasične virulentne markere koje posjeduju 1B i 2-4 biotip Y. enterocolitica, ali posjeduju druge poznate virulentne gene (invA, myfA, ymoA i hreP) koji imaju važnu ulogu u virulenciji 1 A biotipa $Y$. enterocolitica. Sve su učestaliji podatci o izdvajanju tog biotipa iz kliničkog materijala ljudi (Batzilla i sur., 2011.).

\section{Zaključak}

Temeljem mikrobiološke analize kravljeg mlijeka, vrhnja i sira od sirovog mlijeka ustvrđena je prisutnost bakterijske vrste $Y$. enterocolitica u dva (1,8\%) uzorka sirovog mlijeka. Molekularnom je tehnikom Y. enterocolitica potvrđena $\mathrm{u}$ jednom uzorku, što se podudara s rezulatima drugih istraživača. U istraživanim uzorcima sirovog mlijeka dokazan je povećan ukupan broj mikroorganizama od 18,3\%, ali i pojedinih vrsta enterobakterija (Seratia, Morganella i Citrobacter), dok je u uzorcima svježeg sira dokazana E. coli u $32 \%$ uzoraka, S. aureus u $24 \%$ i enterobakterije (Seratia, Morganella i Citrobacter) u 48 $\%$ uzoraka. Zbog zahtjevne identifikacije bakterije $Y$. enterocolitica, kombiniranom primjenom uzgojne i molekularne metode dobivaju se pouzdaniji i brži rezultati identifikacije. Sirovo mlijeko i vrhnje od sirovog mlijeka su mogući izvor patogene bakterijske vrste $Y$. enterocolitica i potencijalni rizik za zdravlje ljudi. $Y$. enterocolitica visoko otporna na procese u proizvodnji hrane (dezinfekcija, niski $\mathrm{pH}$, salinitet, preživljavanje u hladnijim uvjetima), u budućnosti zahtijeva veću pozornost $\mathrm{i}$ veći nadzor $\mathrm{u}$ proizvodnji hrane.

\section{Literatura}

1. AHMED, H. A., A. B. TAHOUN, R. M. ABOU ELEZ, M. I. ABD EL-HAMID and S. S. ABD ELLATIF (2019): Prevalence of Yersinia enterocolitica in milk and dairy products and the effects of storage temperatures on survival and virulence gene expression. Inter. Dairy J. 94, 16-21. 
2. BARUN, G., V. DOBRANIĆ, I. FILIPOVIĆ, K. SEVERIN, J. GRBAVAC i N. ZDOLEC (2016): Sastav mikroflore mekih, polutvrdih i tvrdih sireva na hrvatskom tržištu. Hrv. Vet. Vjes. 24, 7-8.

3. BATZILLA, J., J. HEESEMANNAD and A. RAKIN (2011): The pathogenic potential of Yersinia enterocolitica 1A. Int. J. Med. Microbiol. 301, 556-561.

4. BENIĆ, M., N. MAĆEŠIĆ, L. CVETNIĆ, B. HABRUN, Ž. CVETNIĆ, R. TURK, D. ĐURIČIĆ, M. LOJKIĆ, V. DOBRANIĆ, H. VALPOTIĆ, J. GRIZELJ, D. GRAČNER, J. GRBAVAC and M. SAMARDŽIJA (2018): Bovine mastitis: a persistent and evolving problem requiring novel approaches for its control - a review. Vet. arhiv 88, 535-557.

5. BERNARDINO-VARO, L., E. I. QUINONESRAMIREZ, C. FERNANDEZ and F. J. VASQUEZSALINAS (2013): Prevalence of Yerinia enterocolitica in raw cow's milk collected from stables of Mexico City. J. Food Prot. 76, 694-698.

6. BOLTON, F. J., L. CROZIER and J. K. WILIAMSON (2000): Isolation of Escherichia coli O157 from raw met products. Lett. Appl. Microbiol. 23, 317-321.

7. BUROVIĆ, J. (2020): Isolation of bovine clinical mastitis bacterial pathogens and their antimicrobial susceptibility in the Zenica region in 2017. Vet stn. 51, 47-52.

8. BURSOVÁ, Š., D. NECIDOVÁ HARUŠTIAKOVÁ and B. JANŠTOVÁ (2017): Growth potential of $Y$. enterocolitica in pasteurised cow's and goat's milk stored at $8^{\circ} \mathrm{C}$ and $24^{\circ} \mathrm{C}$. Food Control 73, 1415-1419.

9. CVETNIĆ, Ž. (2013): Infekcije ljudi vrstom Y. enterocolitica. U: Cvetnić, Ž. Bakterijske i gljivične zoonoze. Str 197.

10. CVETNIĆ, L., M. BENIĆ, B. HABRUN, G. KOMPES, M. STEPANIĆ and M. SAMARDŽIJA (2016): Most Common Causes of Mastitis in Cows and Goats in Republic of Croatia. Vet. stn. 47, 109116. (In Croatian).

11. CZUBKOWSKA, A. and J. GRAZYNA ROLA (2019): Yersinia enterocolitica - microbiological hazard in goat's milk. In: Abstract book $8^{\text {th }}$ Congress of European Microbiologists-FEMS, 7-11 July, 2019, Glasgow, Scotland: 1565-1565.

12. DARWISH, S. F., H. A. E. ASFOUR and H. A. ALLAM (2015): Incidence of Yersinia enterocolitica and Yersinia psudotuberculosis in raw milk samples of different animal species using conventional and molecular methods. Alex. J. Vet. Sci., 44, 174-185.

13. EFSA (2018): The European Union summary report on zoonoses, zoonotic agents and food-borne outbreaks in 2017. EFSA Journal 16,12, 5000.

14. ESNAULT, E., A. LABBE, C. HOUNDAYER and M. DENIS (2014): Prévalence de Yersinia enterocolitica sur la viande fraîche de porc, de vollaille et de bœuf à la distribution en France en 2012. Journées Recherche Porcine 46, 57-58.

15. FUKUSHIMA, H. and M. GOMYODA (1986): Growth of Yersinia pseudotuberculosis and Yersinia enterocolitica biotype 3B serotype 03 inhibited on cefsulodin-irgasan-novobiocin agar. J. Clin. Microbiol. 24, 116-120.
16. FUKUSHIMA, H. (1987): New selective agar medium for isolation of virulent Yersinia enterocolitica. J. Clin. Microbiol. 25, 1068-1073.

17. HAHN, G. (1996): Značaj patogenih mikroorganizama u sirovom mlijeku. Mljekarstvo 46, 140-150.

18. HAH (2017): Povezanost između pokazatelja dobrobiti temeljenih na životinji i prisustva bakterije Yersinia enterocolitica kao indikatora sigurnosti hrane. Izvještaj o rezultatima pilot projekta. Hrvatska agencija za hranu 2017. godine.

19. HAMMER, P., W. BOCKELMANN and W. HOFFMANN (2017): Fate of Listeria innocua during production and ripening of smeared hard cheese made from raw milk. J. Dairy Sci. 10, 78467856.

20. HANIFIAN, S. and S. KHANI (2012): Prevalence of virulent Yersinia enterocolitica in bulk raw milk and retail cheese in Northern-West of Iran. Int. J. Food Microbiol. 155, 89-92.

21. HRN EN ISO 10273:2004 Mikrobiologija hrane i stočne hrane-Horizontalna metoda za dokazivanje suspektne patogene Yersinia enterocolitica. Državni zavod za normizaciju i mjeriteljstvo.

22. KALENIĆ, S., B. BEDENIĆ i Z. BOŠNJAK (2013): Enterobakterije. U: Kalenić i sur., Medicinska mikrobiologija. Medicinska naklada. Str. 182-197.

23. KLECZKOWSKI, M., W. KLUCIŃSKI, M. CZERSKI and E. KUDYBA (2017): Association between acute phase response, oxidative status and mastitis in cows. Vet. stn. 48, 177-186.

24. KONOSONOKA, H, I., A. JEMELJANOVS, B. OSMANE, D. IKAUNIECE, G. GULBE (2012): Incidence of Listeria spp. in dairy cows feed and raw milk in Latvia. ISRN Vet. Sci. Article ID 435187. Doi:10.5402/2012/435187.

25. KOZAČINSKI, L., Ž. CVRTILA, M. HADŽIOSMANOVIĆ, D. MAJNARIĆ i B. KUKURUZOVIĆ (2003): Mikrobiološka ispravnost mlijeka i mliječnih proizvoda. Mljekarstvo 53, 17-22.

26. LE GUEREN, A. S., L. MARTIN, C. SAVIN and E. CARNIEL (2016): Yersiniosis in France: overview and potential sources of infection. Int. J. Infect. Dis. 46, 1-7.

27. LJEVAKOVIĆ-MUSLADIN, I. (2007): Prisutnost patogenih mikroorganizama u namirnica $u$ Dubrovačko-neretvanskoj županiji u razdoblju od 2002. do 2006. godine. HČJZ 3, 13-17.

28. LAUKKANEN-NIMIOS, R., M. FREDRIKSSONAKOMAA and H. KORHEALA (2014): Enteropathogenic Yersinia in the pork production chain: Challenges for Control. Compr. Rev. Food Sci. F 13, 1165-1191.

29. MARKOV, K., J. FRECE, D. ČVEK i F. DELAŠ (2009): Listeria monocytogenes i drugi kontaminanti u svježem siru i vrhnju domaće proizvodnje s područja grada Zagreba. Mljekarstvo 59, 225-231.

30. NAGLIĆ, T., D. HAJSIG, J. MADIĆ i LJ. PINTER (2005): Veterinarska mikrobiologija. Yersinia enterocolitica. Veterinarski fakultet Sveučilišta u Zagrebu. Str. 82-83. 
31. SABLJAK, V., K. LISAK-JAKOPOVIĆ, I. BARUKČIĆ, A. PEJAKOVIĆ and R. BOŽANIĆ (2013): Determination of the shelf-life of traditional fresh cheese. Croatian Journal of Food Technology, Biotechnology and Nutrition 8, 115-122.

32. SAMARŽIJA, D., S. DAMJANOVIĆ i T. POGAČIĆ (2007): Staphylococcus aureus u siru. Mljekarstvo 57, 31-48.

33. SAMARŽIJA, D., Š. ZAMBERLIN and T. POGAČIĆ (2012): Psychrotrophic bacteria and their negative effects on milk and dairy products quality. Mljekarstvo 62, 77-95.

34. SCHIEMANN, D. A. (1978): Association of Yersinia enterocolitica with the manufacture of cheese and occurrence in pasteurized milk. Appl. Environ. Microbiol. 36, 274-277.

35. SILVA, I. M. M., R. C. C. ALMEIDA, M. A. O. ALVES and P. F. ALMEIDA (2003): Occurence of Listeria spp. in critical control point and the environment Minas Frescal cheese processing. Int. J. Food Microbiol. 81, 241-248.

36. TRISCHLER-ČEKE, Z., B. BUNJEVAC-HORVATIĆ i V. MATEJIĆ (2008): Yersinia enterocolitica, kao uzročnik enterokolitisa u četrnaestgodišnjeg dječaka. Infekt. glasnik 28, 91-94.

37. VAN DER BROM, R., A. DE JONG, E. VAN ENGELEN, A. HEUVELINK and P. VELLEMA (2020): Zoonotic risks of pathogens from sheep and their milk borne transmission. Small Rumin. Res. Doi: 10.1016/j.smallrumres.2020.106123.

38. Vodič za mikrobiološke kriterije za hranu (2011): Ministarstvo poljoprivrede (3. izmjenjeno izdanje, 2011.).

39. WANNET, W. J. B., M. REESSINK, H. A BRUNINGS and H. M. E. MASS (2001): Detection of pathogenic Yersinia enterocolitica by a rapid and sensitive duplex PCR assay. J. Clin. Microbiol. 39, 4483-4486.

40. ZADERNOWSKA, A., W. CHAJECKAWIERZCHOWSKA and L. LANIEWSKATROKENHEIM (2014): Yersinia enterocolitica: A dangerous, but often ignored, foodborne pathogen. Food Rev. Int. 30, 53-70.

41. ZEBEC, V. (2016): Mikrobiološka kvaliteta mlijeka u proizvodnji sira od sirovog mlijeka. Diplomski rad, Zagreb.

\section{Detection of pathogenic bacteria in raw milk and dairy products with special regard to Yersinia enterocolitica}

Vesna JAKI TKALEC, DVM, PhD, Scientific Associate, Sanja FURMEG, BSc, Maja KIŠ, Mag. Bioproc., PhD, Jadranka SOKOLOVIĆ, DVM, Croatian Veterinary Institute, Veterinary Department Križevci, Križevci, Croatia; Miroslav BENIĆ, DVM, PhD, Scientific Advisor, Luka CVETNIĆ, DVM, $\mathrm{PhD}$, Željko PAVLINEC, Mag. Biol. Mol., Silvio ŠPIČIĆ, DVM, PhD, Scientific Advisor, Croatian Veterinary Institute, Zagreb, Croatia; Željko CVETNIĆ, DVM, PhD, Academician, Croatian Veterinary Institute, Veterinary Department Križevci, Križevci, Croatia

In northwestern Croatia, soft fresh cheese is produced using traditional, unwritten recipes of raw cow milk. Milk is an ideal substrate for the growth and reproduction of numerous microorganisms, many zoonotic agents and the species $Y$. enterocolitica. In this study, 159 samples were tested: 109 samples of raw cow milk and 50 samples of fresh cow cheese and cream. Y. enterocolitica was detected in two (1.8\%) samples of raw milk. E. coli was detected in $16(32 \%)$ of 50 samples of dairy products (cheese and cream). S. aureus was detected in $12(24 \%)$ samples and L. innocua in one (2\%) sample. Additionally, $15(13.8 \%)$ samples of raw milk and $24(48 \%)$ samples of fresh cheese and cream also harboured enterobacteria, identified biochemically as: S. marcescens, S. liquefaciens, M. morganii, C. freundii and C. braakii. Salmonella and L. monocytogenes were not detected in any of the samples. After the biochemical identification, two strains identified as $Y$. enterocolitica were examined at the molecular level, and the molecular test confirmed the result in only one sample, which is comparable to the results of other studies. Due to the demanding identification of the bacterial species $Y$. enterocolitica, the combined application of breeding and molecular methods produces more reliable and faster identification results. Raw milk and crude milk cream are a source of pathogenic microorganisms (E. coli and S. aureus) and other enterobacteria, while this study also found the presence of the pathogenic bacterial species Y. enterocolitica, presenting a potential consumer health risk in the Republic of Croatia. Y. enterocolitica is resistant to food production processes (disinfection, low $\mathrm{pH}$, salinity, survival in cold conditions) and deserves greater attention and supervision in food production in the future.

Key words: Y. enterocolitica; bacteria; raw milk; cheese and cream 